Canadian Studies in Population 41, no. 3-4 (2014): 88-104.

\title{
Income inequality, status seeking, and savings rates in Canada
}

\author{
Alexander Darku ${ }^{1}$
}

\begin{abstract}
This paper uses Canadian provincial-level data and a variant of James Duesenberry's relative income hypothesis proposed by Frank et al. (2010) to examine the relationship between income inequality and savings rates. The theory predicts that increased expenditure of top income earners leads those just below them in the income scale to spend more as well, then the next group also spends more, and so on. This phenomenon is due to people's status seeking behaviour. Hence, increased income inequality will trigger increases in consumption by individuals in all income groups, which in turn leads to declining personal savings rates. The empirical analysis based on this theory led to some interesting findings. First, at the national level, increased income inequality has a significant negative effect on personal savings rates. At the provincial level, the relationship also emerges in eight of ten provinces. Second, both the national and provincial results imply that growth in per capita income that worsens income inequality impacts negatively on personal savings rates. I interpret the results as evidence that social factors such as status-seeking generate consumption interdependence and are significant determinants of consumption and savings decisions of Canadians.
\end{abstract}

Keywords: class identity; savings; income distribution; life cycle models of consumption and savings.

\section{Résumé}

Cet article utilise les données canadiennes au niveau provincial et une variante de l'hypothèse du revenu relatif de James Duesenberry, proposé par Frank et al. (2010), pour examiner la relation entre les inégalités du revenu et le taux d'épargne. La théorie postule que nous imitons le mode de consommation des gens dont les revenus sont immédiatement supérieurs aux nôtres. Il s'agit de la théorie du comportement de la recherche du statut. Ainsi, l'augmentation des inégalités de revenu va déclencher l'accroissement de la consommation par individu dans tous les groupes de revenu, ce qui va conduire à la baisse des taux d'épargne personnelle. L'analyse empirique, basée sur la théorie, conduit à des résultats fort intéressants. Au niveau national, l'augmentation des inégalités des revenus est significativement associée aux taux d'épargne personnelle. De même, à l'échelle provinciale, la relation était présente dans huit des dix provinces. Globalement, tant à l'échelle des provinces et au niveau national, les résultats suggèrent que la croissance du revenu par habitant, lequel accentue les inégalités du revenu, a un impact négatif sur les taux d'épargne personnelle. J'interprète les résultats comme une évidence que les facteurs sociaux tels que la recherche de statut génèrent une interdépendance dans la consommation, et représentent des déterminants important en matière de consommation et d'épargne des Canadiens.

Mots-clés : recherche d'identité, épargne, répartition de revenu, théorie du cycle de vie de la consommation et de l'épargne.

\footnotetext{
1. Associate Director, Prentice Institute for Global Population \& Economy, University of Lethbridge, 4401 University Drive West, Lethbridge AB Canada T1K 3M4; email: alexander.darku@uleth.ca
} 


\section{Introduction}

Most studies have hinted that the standard savings function does not seem to capture all the important variables that can be used to predict why savings can decline during periods of economic growth. It is therefore imperative to go beyond the standard determinants of savings to investigate other possible factors that may impact individual consumption and savings behaviours. One such variable is the distribution of income. Economists and policymakers have long been concerned with the role played by income inequality in the mechanism of household consumption and savings behaviour. ${ }^{2}$ As a result, the relationship between income inequality and savings has received a lot of attention in recent politicaleconomy theory, the general growth literature, and neoclassical consumption theory. Most of the literature has focused on the complex relationship among income inequality, consumption, and savings using different consumption theories. In the case of Canada, there exists an extensive literature on provincial income inequality and its relationship with other social issues such as immigrants, health determinants, women, and homicide. Other studies have focused on the dynamics of income inequality over a long period of time. Saez and Veall (2005) examined the evolution of income inequalities in Canada over the course of the twentieth century. They concluded that though the top income share dropped sharply during World War II, it increased significantly during the 1980s and the 1990s. Few, if any, studies have been done in Canada on the link between income inequalities and savings in Canada.

This paper attempts to contribute by using a variant of the relative income bypothesis originally put forward by James Duesenberry (1949) to examine the relationship between income inequality and savings rates while controlling for other standard determinants of savings. Specifically, the paper explores the mechanism through which changes in income inequality in Canada may contribute to consumption and savings patterns. Income inequality in Canada has risen considerably over the past three decades (Brzozowski et al. 2010), and the personal savings rate has declined over the same period. According to Statistics Canada, the personal savings rate has declined considerably, from double digits to single digits over the past two decades. This implies that over the same period consumption expenditure has grown more rapidly than what traditional economic models would predict. This low and falling personal savings rates has considerable and important implications for the performance of the Canadian economy. On the macroeconomic level, falling savings rates mean too little investment and low economic growth in the future. Frank et al. (2010) classified the above phenomenon as expenditure cascade when explaining the pervasive pattern of worsening income inequality and declining savings rates in the United States. They used a variant of the relative income hypothesis to describe a process whereby increased expenditure of top income earners leads to those just below them in the income scale to spend more as well, then the next group also spends more, and so on.

Theoretical models of consumption and savings, and their empirical applications abstract from social and cultural forces that may help explain households' savings decision. Wisman (2009) argued that it is important to incorporate human generic heritage and cultural conditioning into preference functions in order to capture the complete set of variables that impacts our choices. His argument is in line with Duesenberry's view that a real understanding of the problem of consumer behaviour must begin with a full recognition of the social character of consumption patterns. The arguments are also consistent with Bosworth's (1993) claim that differences in cultures may be important in explaining savings behaviour, because international differences in savings rates are not well explained by traditional economic variables. However, Wisman (2009) and Bosworth (1993) did not explicitly

2. This paper focuses on the distribution of income (income inequality), instead of the distribution of economic assets (wealth inequality). 
model and test household savings decisions that incorporate cultural and social conditions. Two recent studies by Jin et al. (2011) and Frank et al. (2010) have proposed and tested consumption theories that do explicitly incorporate social and cultural forces. According to Jin et al. (2011), people's desire to improve their social status generates a positive link between income inequality and savings. Since people care about their social status, they will always save to accumulate wealth that will put them in a higher social status. Rising income inequality widens the benefit gap between the highstatus and low-status groups; hence, status-seeking individuals will save more in order to reach higher status more quickly. In the Frank et al. (2010) expenditure cascade model, rising income inequality leads to declines in savings rates, since consumers seek to signal their social-status with present consumption. This is because as inequality worsens and the top income earners increase their consumption, they shift the frame of reference that defines consumption standards to those just below them-who, in turn, shift their frame of reference to the next lower income group, and so on. The model therefore predicts that growing income inequality will lead to declining savings rates. In this paper, I adopt the Frank et al. (2010) framework in the empirical analysis, to provide new empirical evidence on the role social forces play in the relationship between income inequality and savings rates in Canada.

The rest of the paper is organized as follows. Section 2 presents a brief review of the relevant literature. Section 3 outlines a brief discussion of the relationship between income inequality and savings rates in Canada. Section 4 presents the theoretical model that explicitly incorporates the role social forces play in the relationship between income inequality and savings rates. Section 5 presents the empirical analysis of the effect of income inequality on savings rates. Section 6 concludes the paper and offers some policy implications.

\section{Review of the literature}

The theoretical discussion on the relationship between savings, economic growth, and wealth dates back to Fisher (1930) and Keynes (1936). According to Keynes, income inequality would slow down economic growth because the marginal propensity to consume decreases as the income of an individual increases. However, these theories do not explicitly discuss the relationship between savings and income distribution. James Duesenberry's relative income hypothesis explicitly discussed that relationship by proposing that one's consumption depends on the current income of others. Hence, for any given relative income distribution, a family's savings rate will depend on its position in the income distribution. Further works by Modigliani and Brumberg (1951), Friedman (1957), Ando and Modigliani (1963), and later, Kotlokoff and Summers (1981) provided new theoretical frameworks on the relationship between income distribution and savings. According to their models, poor or rich households spend a constant proportion of their permanent income; hence, savings rates remain stable over time and are independent of household income distribution. The theories also suggest that people with higher current income save more than their lower income counterparts. Over the decades, these models have become popular and formed the basis of most theoretical and empirical studies on the relationship among income, spending, and savings.

Theoretical works on growth and development that emphasize the relationship between income inequalities and savings rates have yielded mixed predictions. According to Kaldor (1957), income inequality should have a positive relationship with savings, because the rich have higher marginal propensity to save and the poor have zero propensity to save. Income inequality, he claimed, would lead to increased capital accumulation for economic growth. Though Pasinetti (1962) differs in his approach by assuming that workers do not have zero marginal propensity to save because they own shares on the capital stock, the implications for the share of profit in income are similar to those 
obtained by Kaldor (1957). This is casually referred to in the literature as the Kaldor-Pasinetti channel. Lewis (1954) emphasized the positive relationship between income inequality and savings rates by assuming that workers may not save much since their wage earnings are at the subsistence level, but entrepreneurs will save high proportion of their income. As documented by Deaton (1992), most of the studies based on neoclassical consumption theories also suggest a positive relationship between income inequality and personal savings. On the other hand, recent political-economic research demonstrates a negative relationship between income inequality and savings rates. Alesina and Rodrik (1994) show that if higher income inequality is associated with socio-political instability, it can reduce investment and reduce the savings rate. Alesina and Rodrik (1996) demonstrated that income inequality will lead to lower aggregate savings if rising inequality leads to higher taxation for redistributive purposes. Dornbusch and Edwards (1991), Aghion et al. (1999), and Persson and Tabellini (1994) all show similar indirect negative link from increased income inequality through investment growth to low aggregate savings. Other theoretical studies of households' decisions to save are based explicitly or implicitly on the life-cycle model which postulates that households save or dis-save in order to smooth their consumption over their life span. However, Borsch-Supan (2001) and Thaler (1994) argued that the life-cycle models fail to capture actual savings behaviour of household.

Following the theoretical discussion, the empirical literature has also established a wealth of mixed evidence. Most of the cross-section micro-data studies, such as Bunting (1991) and Dynan et al. (1996), suggest a positive relationship. Cook (1995) used cross-section macro data on 49 less developed countries to conclude that countries with greater income inequalities tend to have higher savings rates. Sahota (1993) used similar analysis to arrive at the same conclusion. Other studies that used data on both developed and developing countries have also arrived at the same conclusion (Smith 2001; Venieris and Gupta 1986; Honk 1995). Similarly, Schmidt-Hebbel and Serven (2000) used cross-section and panel data analysis for both developed and developing countries but concluded that there was no consistent relationship between savings and inequality. Some regression analysis yielded a positive relationship, while some yielded a negative relationship and some showed no relationship at all. Their result is similar to earlier studies by Della Valle and Oguchi (1979), Edwards (1996), and Musgrove (1980). However other studies have found different results. Li and Zou (2004) found that income inequality has a negative effect on private savings. Blinder (1975) used aggregate US data and found a negative relationship between income inequality and average propensity to save.

As mentioned in the previous section, Jin et al. (2011) and Frank et al. (2010) have proposed and tested consumption theories that explicitly incorporate social and cultural forces. Whereas the Jin et al. (2011) model generates a positive link between income inequality and savings through accumulation of wealth for status seeking, the Frank et al. (2010) expenditure cascade model predicts that rising income inequality leads to declining savings rates, since consumers seek to signal their social-status with present consumption. Against the background of the predictions of the theoretical models and the mixed empirical evidences, the recent rise in income inequality coupled with falling personal savings rates in Canada becomes an empirical question that needs to be addressed comprehensively.

\section{Income inequality and savings in Canada: A brief survey}

The rise in income inequality and the low and falling savings rates in the United States are two important economic realities that have received a lot of attention, both in the media and policymaking circles. Canada is no less affected by the situation, both at the national and provincial levels. These patterns pose many economic challenges to any nation. Beside its potential economic impact, income inequality has a significant impact on socio-political issues. Daly et al. (2001) linked inequal- 


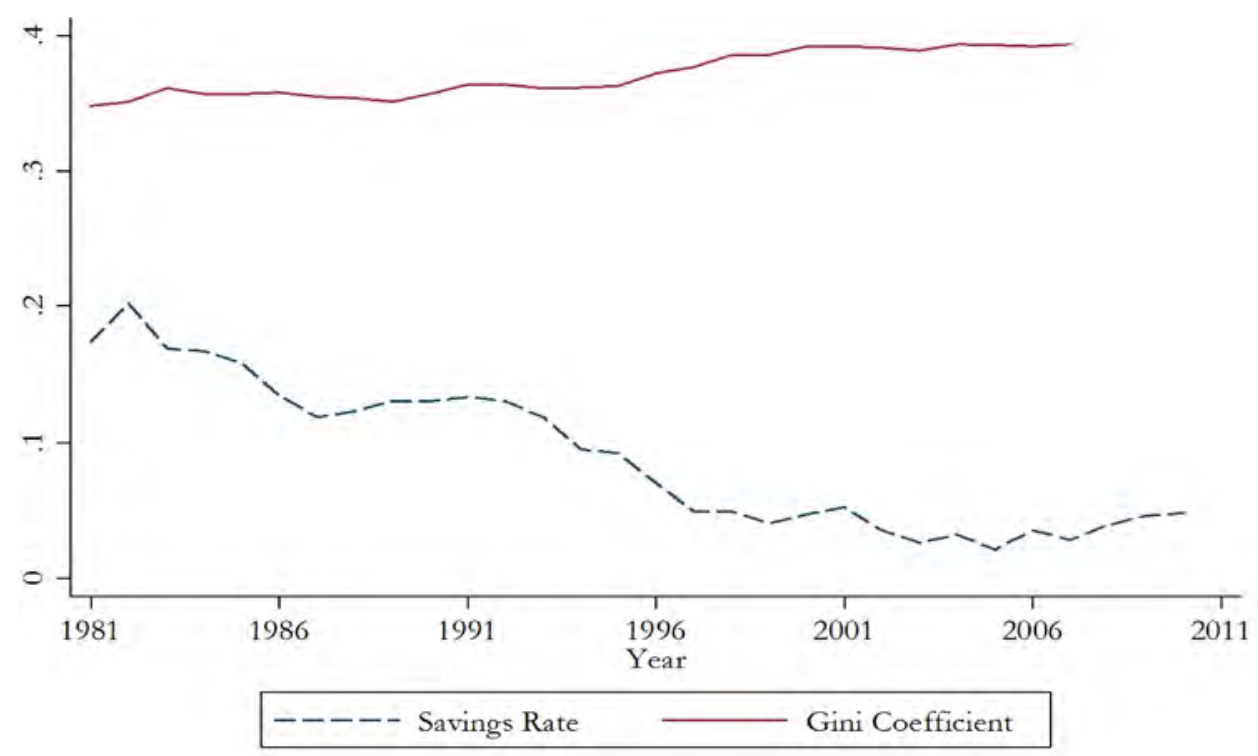

Figure 1. Savings rate and Gini Coefficient in Canada.

ity to homicide rates at both national and provincial levels; Raphael (2002) discussed the impact of income inequality on health; Osberg (2012) linked increasing inequality to economic instability; and Wilson and Macdonald (2010) looked at income inequality and aboriginal people in Canada.

All indicators of income inequality in Canada depict an increasing trend for the past three decades, both at the national and provincial levels. During the period 1941 to 1971, the Canadian economy experienced dramatic technological progress and social changes that led to a highly urbanized and industrialized society. Throughout the period, aggregate income shares remained stable. The same era witnessed the adherence to the Keynesian full employment macroeconomics and welfare state social policies that ensured that capitalists earned increasing dividends and workers experienced rising wages. Economic progress trickled down almost evenly to all income groups, and income shares were quite stable. The stagflation experience of early 1970s marked the beginning of a shift from the Keynesian macroeconomic accommodation, with welfare state policies to neoliberal approaches and reduced social policies. During the 1980s and 1990s, stable income shares changed drastically. Canada, in this period, like most industrialized countries, experienced two of its most severe recessions since the great recession of the 1930s. The Canadian government in this period reduced its role in the redistribution of income. During the same period, growth in wages coincided with economic growth, but it was the incomes of those at the very top that grew most significantly. This led to an increase in overall income inequality (measured by the after-tax Gini coefficient). During the same period, personal savings rates trended downwards, as depicted in Figure 1.

Table 1. Share of after-tax income received by each quintile of families and unattached individuals.

\begin{tabular}{lrrrrr}
\hline & 1976 & 1981 & 1991 & 2001 & 2010 \\
\cline { 2 - 6 } Lowest 20\% & 4.9 & 5.3 & 5.4 & 4.8 & 4.8 \\
Second 20\% & 11.5 & 11.9 & 11.3 & 10.7 & 10.7 \\
Middle 20\% & 17.9 & 18.1 & 17.2 & 16.4 & 16.2 \\
Fourth 20\% & 24.7 & 24.9 & 24.6 & 24.0 & 24.0 \\
Highest 20\% & 41.0 & 39.8 & 41.5 & 44.0 & 44.3 \\
\hline
\end{tabular}

Source: Statistics Canada. CANSIM Table 202-0405-Upper Income Limits and Income Shares. 
Table 1 presents summary data on percentage shares of earned income by each fifth (quintile) of Canadian households, from poorest to richest, between 1976 and 2010. The share of the bottom 20 per cent increased from 4.9 per cent in 1976 to 5.4 per cent in 1991, before falling to 4.8 per cent in 2010. The share of income of the top 20 per cent was 41 per cent in 1976, increasing to 44.0 per cent in 2001 before increasing further to 44.3 percent by 2010. Though these changes are less pronounced than in the case of United States and United Kingdom, the situation is similar to that of the Unites States if we look at the income share of the top 10 per cent, whose income share has increased dramatically over the past three decades. ${ }^{3}$ The growth in income shares of the top 10 and 20 per cent became possible because the middle 60 per cent of the income distribution lost 3.2 percentage points, moving from 54.1 to 50.9 per cent of total household income. These dynamics are captured in the trend in the Gini coefficient as a measure of inequality. The Gini coefficient has increased, from 0.348 in 1981 to 0.364 in 1991 and finally to 0.394 in 2007. From Figure 1, it can be seen that the personal savings rate has also decreased precipitously, from 17.4 per cent in 1981 to 13.3 per cent in 1991, and finally to as low as 4.8 per cent in 2010.

At the provincial level, there are some marked differences in the degree of income inequality. This can be seen in Table 2. Whereas the Gini coefficient has trended upwards for all provinces, Prince Edward Island is the only province that experienced an appreciable decline in the Gini coefficient between 1976 and 2007. The province has essentially progressed from being the seventh most equitable province in Canada to being the most equitable province over the period. Among the other provinces, Ontario, Quebec, Alberta, New Brunswick, Nova Scotia, Newfoundland and Labrador, and British Columbia have experienced the greatest increase in the Gini coefficient since 1976. Manitoba and Saskatchewan have had a more moderate increase in the Gini coefficient. New Brunswick is still the second most equitable province, but the extent of inequality within the province has increased by about 7.6 per cent. The situation is similar to Nova Scotia, which has declined from the second most equitable province in 1976 to the fourth most equitable in 2007. However, within the province inequality deteriorated by 8.8 per cent. Newfoundland, which was the most equitable province in 1976 , became the third most equitable in 2007, with internal inequality increasing by 8.8 per cent.

A look at the inequality ratios (ratio of income received by the top 20 per cent to income received by the bottom 20 per cent) in Table 3 reveals even more pronounced variations in income inequality among the provinces. For instance, in Newfoundland, which was the most equitable province in Canada in 1976, the top 20 per cent income group received 6.57 times in after-tax income for every dollar of the 20 per cent with the lowest income. However, the corresponding value for 2010 was 8.11 times. Prince Edwards Island is again the most equitable province, with an inequality ratio of 6.38, having improved significantly from 8.71 in 1976. Manitoba also progressed, from the highest inequality ratio of 11.64 in 1976 to the second-best of 7.69 in 2010. Saskatchewan also improved marginally, from 9.44 in 1976 to 8.98 in 2010. The ratios for British Columbia, Ontario, and Alberta trended downward from 1976 to 1995, after which they trended upwards to become the three most unequal provinces.

Beside the evidence that provincial inequality is on the rise in Canada, Figures 2, 3 and 4 show that between 1981 and 2010, provincial savings rates have been declining, and in some provinces they have become negative. All ten provinces had double-digit savings rates in the early 1980s, by 1996 all of them had single-digit savings rates, and a few years later, five out of the ten had negative savings rates. Alberta is the only province that has gone back to double-digit savings rates since 2006. Similar to the national level, there seems to be a negative relationship between income inequality and savings rates at the provincial level.

3. See Saez and Veall (2005) for detailed analyses of the evolution of income of the top 10 per cent. 


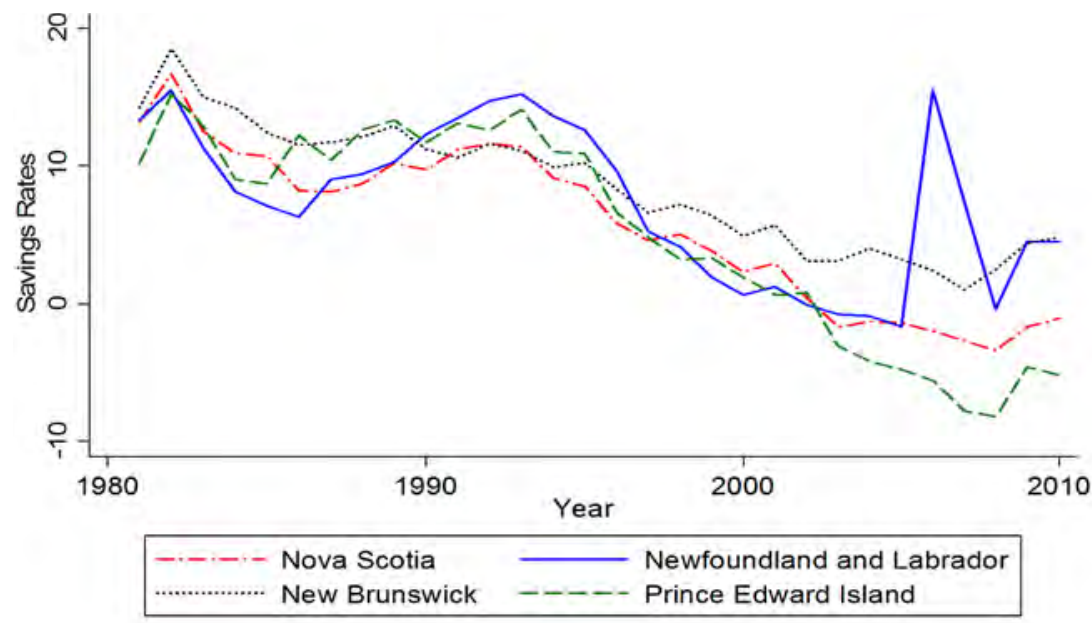

Figure 2. Savings rates - Atlantic provinces.

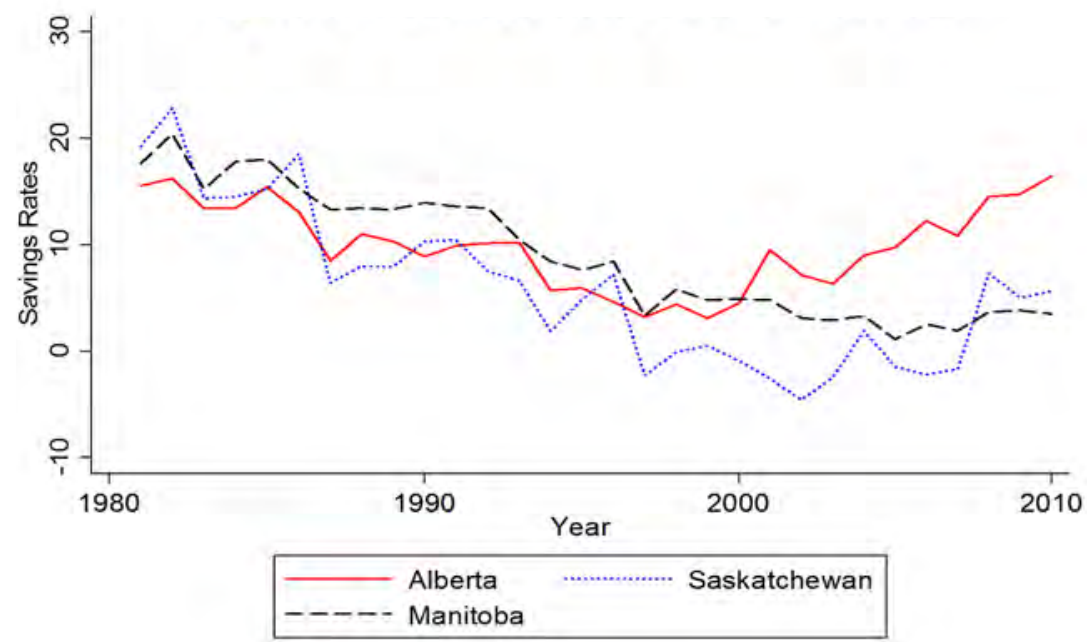

Figure 3. Savings rates - Prairie provinces.

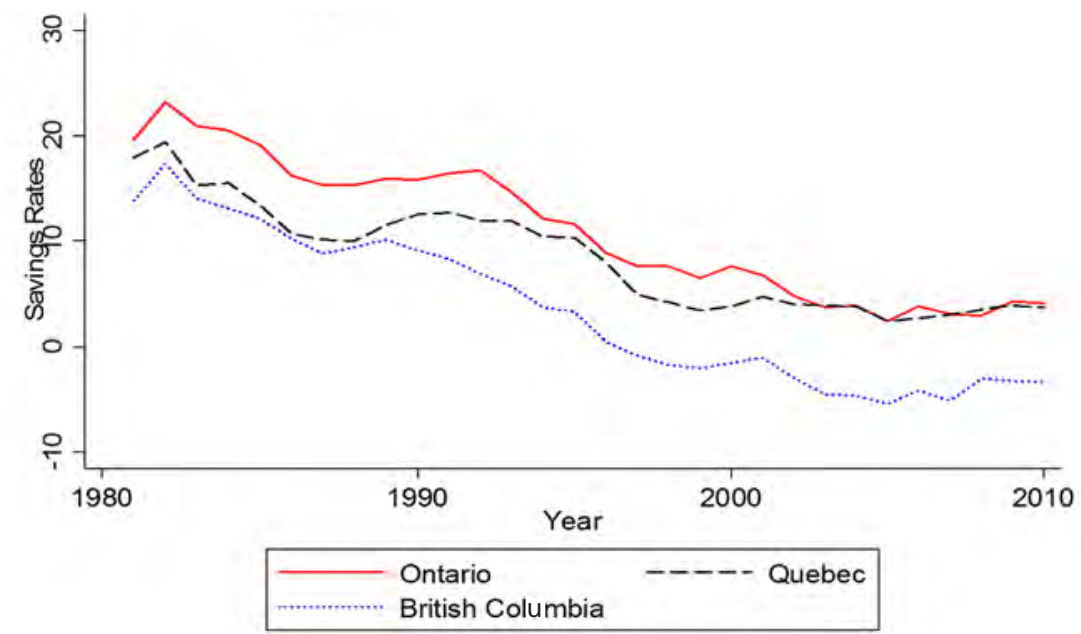

Figure 4. Savings rates - Ontario, Quebec, and British Columbia. 
Darku: Income inequality, status seeking, and savings rates in Canada

Table 2. After-tax Gini coefficients, by province.

\begin{tabular}{|c|c|c|c|c|c|c|c|c|c|c|}
\hline Year & $\mathrm{NL}$ & $\mathrm{PE}$ & $\mathrm{NS}$ & NB & QC & $\mathrm{ON}$ & MB & SK & $\mathrm{AB}$ & $\mathrm{BC}$ \\
\hline 1976 & 0.341 & 0.376 & 0.342 & 0.342 & 0.353 & 0.361 & 0.373 & 0.384 & 0.379 & 0.367 \\
\hline 1977 & 0.335 & 0.348 & 0.355 & 0.353 & 0.345 & 0.348 & 0.369 & 0.366 & 0.359 & 0.355 \\
\hline 1978 & 0.329 & 0.396 & 0.361 & 0.334 & 0.341 & 0.354 & 0.379 & 0.366 & 0.368 & 0.367 \\
\hline 1979 & 0.333 & 0.351 & 0.348 & 0.336 & 0.352 & 0.345 & 0.361 & 0.376 & 0.353 & 0.362 \\
\hline 1980 & 0.350 & 0.355 & 0.340 & 0.332 & 0.344 & 0.342 & 0.364 & 0.359 & 0.373 & 0.364 \\
\hline 1981 & 0.327 & 0.339 & 0.342 & 0.352 & 0.345 & 0.338 & 0.358 & 0.376 & 0.346 & 0.354 \\
\hline 1982 & 0.325 & 0.335 & 0.347 & 0.351 & 0.344 & 0.343 & 0.359 & 0.363 & 0.358 & 0.358 \\
\hline 1983 & 0.337 & 0.356 & 0.359 & 0.367 & 0.346 & 0.364 & 0.357 & 0.378 & 0.363 & 0.358 \\
\hline 1984 & 0.330 & 0.348 & 0.352 & 0.350 & 0.356 & 0.353 & 0.351 & 0.365 & 0.357 & 0.363 \\
\hline 1985 & 0.346 & 0.341 & 0.367 & 0.342 & 0.347 & 0.351 & 0.350 & 0.372 & 0.352 & 0.375 \\
\hline 1986 & 0.329 & 0.331 & 0.353 & 0.330 & 0.355 & 0.352 & 0.344 & 0.374 & 0.360 & 0.361 \\
\hline 1987 & 0.332 & 0.337 & 0.343 & 0.344 & 0.352 & 0.349 & 0.349 & 0.355 & 0.358 & 0.363 \\
\hline 1988 & 0.316 & 0.328 & 0.343 & 0.330 & 0.349 & 0.351 & 0.350 & 0.354 & 0.351 & 0.347 \\
\hline 1989 & 0.315 & 0.346 & 0.350 & 0.335 & 0.342 & 0.351 & 0.343 & 0.351 & 0.352 & 0.341 \\
\hline 1990 & 0.330 & 0.330 & 0.338 & 0.334 & 0.352 & 0.352 & 0.342 & 0.362 & 0.356 & 0.367 \\
\hline 1991 & 0.346 & 0.344 & 0.336 & 0.342 & 0.357 & 0.362 & 0.344 & 0.357 & 0.366 & 0.367 \\
\hline 1992 & 0.343 & 0.327 & 0.352 & 0.348 & 0.353 & 0.357 & 0.361 & 0.373 & 0.378 & 0.374 \\
\hline 1993 & 0.332 & 0.322 & 0.339 & 0.341 & 0.348 & 0.361 & 0.344 & 0.357 & 0.362 & 0.367 \\
\hline 1994 & 0.336 & 0.320 & 0.355 & 0.339 & 0.352 & 0.363 & 0.355 & 0.351 & 0.357 & 0.365 \\
\hline 1995 & 0.331 & 0.326 & 0.348 & 0.341 & 0.355 & 0.363 & 0.347 & 0.360 & 0.359 & 0.363 \\
\hline 1996 & 0.338 & 0.325 & 0.345 & 0.348 & 0.361 & 0.376 & 0.346 & 0.354 & 0.365 & 0.378 \\
\hline 1997 & 0.332 & 0.327 & 0.357 & 0.352 & 0.366 & 0.378 & 0.354 & 0.348 & 0.379 & 0.383 \\
\hline 1998 & 0.358 & 0.350 & 0.370 & 0.361 & 0.372 & 0.384 & 0.367 & 0.369 & 0.396 & 0.390 \\
\hline 1999 & 0.361 & 0.366 & 0.371 & 0.352 & 0.364 & 0.391 & 0.358 & 0.360 & 0.379 & 0.391 \\
\hline 2000 & 0.368 & 0.362 & 0.372 & 0.365 & 0.376 & 0.396 & 0.364 & 0.369 & 0.385 & 0.390 \\
\hline 2001 & 0.360 & 0.358 & 0.376 & 0.370 & 0.378 & 0.392 & 0.362 & 0.366 & 0.384 & 0.400 \\
\hline 2002 & 0.365 & 0.359 & 0.376 & 0.370 & 0.374 & 0.392 & 0.370 & 0.367 & 0.377 & 0.408 \\
\hline 2003 & 0.364 & 0.347 & 0.370 & 0.371 & 0.370 & 0.390 & 0.357 & 0.374 & 0.394 & 0.395 \\
\hline 2004 & 0.365 & 0.342 & 0.372 & 0.371 & 0.374 & 0.400 & 0.369 & 0.381 & 0.390 & 0.395 \\
\hline 2005 & 0.365 & 0.336 & 0.375 & 0.369 & 0.380 & 0.394 & 0.373 & 0.396 & 0.383 & 0.398 \\
\hline 2006 & 0.364 & 0.343 & 0.374 & 0.367 & 0.375 & 0.391 & 0.376 & 0.395 & 0.389 & 0.400 \\
\hline 2007 & 0.371 & 0.329 & 0.372 & 0.366 & 0.376 & 0.392 & 0.380 & 0.385 & 0.394 & 0.401 \\
\hline
\end{tabular}

Source: Statistics Canada. CANSIM Table 202-0705-Income Statistics Division.

\section{Theory and model specification}

To test for the relationship between savings rates and income inequality in Canada, I draw upon the theoretical work of Frank et al. (2010), which suggests that increases in income inequality will negatively impact overall savings rates through what they call an expenditure cascade. The utility function is given as:

$$
u_{i}=\left(\theta_{i}\left(1-s_{i}\right)\right)^{1-\alpha} s_{i}^{\alpha}
$$

where $\theta_{i}$ is the income of individual $i$ and $s$ is the savings rate which determines the individual's current consumption. From the utility function in equation (1), optimal consumption is given by:

$$
c_{i}=\left(1-s_{i}\right) \theta_{i}=(1-\alpha) \theta_{i}
$$


Canadian Studies in Population 41, no. 3-4 (2014): Prentice Institute Special Issue

Table 3. After-tax income inequality quotients, by province.

\begin{tabular}{|c|c|c|c|c|c|c|c|c|c|c|}
\hline Year & $\mathrm{NL}$ & $\mathrm{PE}$ & NS & NB & $\mathrm{QC}$ & $\mathrm{ON}$ & $\mathrm{MB}$ & SK & $\mathrm{AB}$ & $\mathrm{BC}$ \\
\hline 1976 & 6.57 & 8.71 & 7.11 & 7.96 & 7.77 & 8.29 & 11.64 & 9.44 & 9.33 & 8.60 \\
\hline 1977 & 7.00 & 8.19 & 8.31 & 7.86 & 7.86 & 8.36 & 9.90 & 9.09 & 11.51 & 8.93 \\
\hline 1978 & 6.49 & 12.03 & 8.33 & 7.27 & 7.24 & 8.89 & 11.56 & 8.54 & 9.04 & 9.07 \\
\hline 1979 & 6.64 & 7.55 & 7.49 & 6.82 & 7.84 & 7.69 & 8.55 & 8.91 & 7.88 & 8.57 \\
\hline 1980 & 7.51 & 7.82 & 7.15 & 6.77 & 7.56 & 7.67 & 8.56 & 7.98 & 8.69 & 9.23 \\
\hline 1981 & 6.23 & 6.51 & 6.91 & 7.11 & 7.33 & 7.09 & 7.98 & 8.79 & 7.49 & 8.14 \\
\hline 1982 & 6.13 & 6.25 & 7.05 & 7.20 & 7.31 & 7.09 & 7.74 & 8.26 & 8.02 & 8.31 \\
\hline 1983 & 6.38 & 8.12 & 7.43 & 7.98 & 7.43 & 8.10 & 7.50 & 8.31 & 9.07 & 7.92 \\
\hline 1984 & 6.24 & 7.92 & 7.20 & 7.25 & 7.77 & 7.48 & 7.41 & 8.30 & 8.46 & 7.77 \\
\hline 1985 & 6.72 & 6.69 & 7.50 & 6.86 & 7.11 & 7.20 & 6.97 & 9.27 & 7.46 & 8.38 \\
\hline 1986 & 6.34 & 6.22 & 7.05 & 6.54 & 7.38 & 7.21 & 6.91 & 8.65 & 7.72 & 7.72 \\
\hline 1987 & 6.45 & 6.46 & 6.83 & 6.83 & 7.12 & 7.07 & 6.95 & 7.54 & 7.66 & 7.67 \\
\hline 1988 & 5.71 & 6.09 & 6.89 & 6.17 & 7.04 & 7.21 & 6.97 & 7.18 & 7.44 & 7.00 \\
\hline 1989 & 5.57 & 6.78 & 6.86 & 6.46 & 6.71 & 7.02 & 6.68 & 7.20 & 8.04 & 7.35 \\
\hline 1990 & 6.21 & 6.22 & 6.40 & 6.39 & 7.09 & 7.25 & 6.71 & 7.81 & 7.70 & 8.49 \\
\hline 1991 & 7.27 & 7.09 & 6.37 & 6.63 & 7.44 & 7.53 & 6.56 & 7.66 & 7.85 & 7.92 \\
\hline 1992 & 6.73 & 6.24 & 6.97 & 6.83 & 7.21 & 7.74 & 7.51 & 8.10 & 8.33 & 8.27 \\
\hline 1993 & 6.58 & 5.98 & 6.49 & 6.79 & 6.95 & 7.51 & 6.96 & 7.42 & 7.98 & 8.10 \\
\hline 1994 & 6.35 & 5.77 & 7.29 & 6.66 & 7.09 & 7.69 & 7.23 & 6.95 & 7.70 & 7.79 \\
\hline 1995 & 6.27 & 6.35 & 6.80 & 6.52 & 7.25 & 7.56 & 6.81 & 7.61 & 7.75 & 7.92 \\
\hline 1996 & 6.57 & 6.21 & 6.91 & 6.83 & 7.38 & 8.29 & 6.68 & 7.25 & 7.83 & 8.61 \\
\hline 1997 & 6.38 & 6.14 & 7.19 & 7.20 & 7.89 & 8.50 & 7.00 & 6.85 & 8.88 & 9.09 \\
\hline 1998 & 7.23 & 6.83 & 8.59 & 7.25 & 8.02 & 9.02 & 7.48 & 8.24 & 10.21 & 10.02 \\
\hline 1999 & 7.56 & 7.55 & 9.38 & 7.11 & 7.70 & 9.48 & 7.29 & 7.75 & 8.83 & 10.29 \\
\hline 2000 & 7.54 & 7.37 & 8.12 & 7.74 & 8.06 & 9.61 & 7.43 & 8.18 & 9.04 & 12.51 \\
\hline 2001 & 7.32 & 6.73 & 8.21 & 7.80 & 8.13 & 9.19 & 7.30 & 8.16 & 9.17 & 11.10 \\
\hline 2002 & 7.80 & 6.76 & 7.94 & 7.74 & 7.80 & 9.15 & 7.71 & 7.62 & 8.83 & 10.79 \\
\hline 2003 & 7.89 & 6.77 & 7.81 & 7.81 & 7.71 & 8.94 & 7.23 & 8.17 & 9.89 & 9.76 \\
\hline 2004 & 7.76 & 6.85 & 8.42 & 7.81 & 7.80 & 9.49 & 7.65 & 8.90 & 9.39 & 10.71 \\
\hline 2005 & 7.39 & 6.45 & 8.52 & 8.10 & 8.62 & 9.57 & 7.96 & 9.34 & 8.94 & 10.02 \\
\hline 2006 & 7.83 & 6.98 & 8.71 & 8.00 & 7.89 & 9.32 & 8.09 & 9.54 & 9.08 & 10.23 \\
\hline 2007 & 8.23 & 6.46 & 8.00 & 7.69 & 8.06 & 9.38 & 8.31 & 8.84 & 9.04 & 10.07 \\
\hline 2008 & 8.38 & 6.97 & 8.25 & 8.16 & 8.13 & 9.25 & 7.83 & 8.68 & 8.02 & 9.89 \\
\hline 2009 & 7.73 & 6.37 & 8.70 & 8.12 & 8.04 & 9.45 & 7.43 & 8.64 & 9.02 & 9.96 \\
\hline 2010 & 8.11 & 6.38 & 8.02 & 7.74 & 8.27 & 9.40 & 7.69 & 8.98 & 8.65 & 11.15 \\
\hline
\end{tabular}

Source: Statistics Canada. CANSIM Table 202-0705-Income Statistics Division.

and the savings rate is constant and independent of own income and others' consumption. To make the model reflect the effect of others' consumption, the individual $i$ is assumed to compare her consumption to a set of consumption levels of neighbours $N(i)$. Let $n_{i}=|N(i)|$ represent the number of individuals in the set and assume that consuming more than a neighbour makes an individual happier in the form of gaining more utility, while consuming less than a neighbour is a source of worry and results in a loss of utility. This social effect of relative consumption and consumption interdependence generates the expenditure cascade in the model. Given the assumptions above, the sum of differences with each neighbour enters the individual's utility function with the strength of concern for 
Darku: Income inequality, status seeking, and savings rates in Canada

relative consumption represented by the parameter $\pi$. The Cobb-Douglas form of the individual's utility function becomes:

$$
u_{i}=\left(\theta_{i}\left(1-s_{i}\right)-\pi \sum_{j \in N(i)}\left[\theta_{j}\left(1-s_{j}\right)-\theta_{i}\left(1-s_{i}\right)\right]\right)^{1-\alpha} s_{i}^{\alpha} .
$$

The optimal savings rate, obtained from the first order condition from the modified utility function, is:

$$
s_{i}=\alpha-\frac{\alpha \pi}{\left(1+n_{i} \pi\right) \theta_{i}} \sum_{j \in N(i)} \theta_{j}\left(1-s_{j}\right) .
$$

The optimal savings rate in equation (4) is no longer constant but is increasing in own income and decreasing in the total consumption of neighbours. This implies that the savings rates of individuals $i$ and $j$ are not independent, in the sense that when an individual $i$ reduces her savings rate, it will affect the savings rate of individual $j$, which, will, in turn, affect individual $j$ s neighbour, and so on. To calculate the equilibrium savings rate in the economy, complete information on each individual's income and the pattern of interactions in the model is required.

The consumption game individuals' play in this model exhibits strategic complementarity. When individual $i$ increases his consumption, this will increase his neighbours' marginal utility of consumption, so they will also increase their consumption. This will then increase the marginal utility of consumption of the 2nd-order neighbours, who will also increase their consumption, and so on. This strategic complementarity of consumption is what creates the negative relationship between income inequality and savings rates. Assume there is growth in income in the economy, mainly driven by the rich. If the richest individual $i$ responds to the increase in income by increasing her consumption, then her neighbours experiencing an increase in their marginal utility will also increase their consumption. This ratchet effect in consumption in society will lead to everyone increasing their consumption, even if they do not experience an increase in income. Hence, the savings rate will decrease as a result of an increase in income inequality. Thus, it is important to investigate if this consumption complementarity could be used to explain the relationship between income inequality and savings rates in Canada. For this purpose, I estimate a linear regression model based on equation (4), augmented to include other standard savings rate determinants.

$$
s_{i t}=\alpha_{i}+\beta_{1} \text { Gini }_{i t}+\beta_{2} P C I g_{i t-1}+\beta_{3} D E P_{i t}+\beta_{4} R_{i t}+\varepsilon_{i t}
$$

for $i=1,2, \ldots N$ and $t=1,2, \ldots T$, where $N$ is the number of provinces and $T$ is the time period. In equation (5), the dependent variable $s_{i t}$ is the after-tax savings rate, $\alpha_{i}$ is the constant term, and $\varepsilon_{i t}$ is the error term assumed to be normally distributed with zero mean and constant variance $\sim\left(0, \sigma_{\varepsilon}^{2}\right)$. The independent variables are: Gini (after-tax Gini Coefficient), PCIg (real per capita income growth), DEP (dependency ratio), and $R$ (real interest rate). The after-tax savings rate variable is measured by provincial personal savings rates. The after-tax Gini Coefficient is used as a measure of income inequality. The real per capita income growth is measured as growth rate of the provincial real GDP divided by the total provincial population. It enters the model with a lag, due to its possible contemporaneous correlation with the income inequality variable. The interest rate is measured as the real bank rate (nominal bank rate adjusted for inflation, measured by a GDP deflator). Finally, the dependency ratio is measured by the sum of total population 14 years and younger plus the population 66 year and older, relative to the population between 15 years and 65 years (the economically active adults). 
The theory put forward by Frank et al. (2010) states that a rise in income inequality will lead to a decline in savings rates, hence, $\beta_{1}$ is expected to be negative. $\beta_{2}$ could be positive or negative, depending on the nature of the growth in per capita income. If growth in per capita income is mainly driven by growth in income of the rich, then income inequality will worsen and savings rates will fall. On the other hand, if growth in per capita income is mainly driven by growth in income of the poor, then income inequality will fall and savings rates will increase. Finally, if growth in per capita income occurred evenly for all income groups, then income inequality will not change. However, according to economic theory, if all individuals' income increased, savings rates would also increase. $\beta_{3}$ could be positive or negative, depending on the demographic composition of the work force. Finally, $\beta_{4}$ is expected to be positive. A rise in the real interest rate will induce individuals to save more.

\section{Estimation and discussion of results}

The theoretical model discussed in the previous section uses economic and social factors to unambiguously predict a negative relationship between income inequality and savings rate. It is important to find out if the predicted relationship holds for Canada. In this section, I estimate the model, using panel data on all the ten provinces in Canada. All the data used for the study were obtained from the online database of Statistics Canada, CANSIM II. The data sample for the analysis covers the period 1981-2010, which is dictated by data availability and consistency. The data set is balanced, since we have complete data for all the ten provinces.

Table 4. Income inequality and Personal Savings rate (Gini Coefficient).

\begin{tabular}{|c|c|c|c|}
\hline & OLS & Random effects & Fixed effects \\
\hline Gini $_{i}$ & $-0.631(3.712)^{* * *}$ & $-0.879(4.146)^{* * *}$ & $-0.896(4.036)^{* * *}$ \\
\hline $\mathrm{PCIg}_{i-1}$ & $-0.210(2.121)^{* *}$ & $-0.170(2.073)^{* *}$ & $-0.164(1.976)^{* *}$ \\
\hline$D E P_{i}$ & $-0.081(1.328)$ & $0.171(1.763)^{*}$ & $0.269(2.468)^{* *}$ \\
\hline$R_{i}$ & $1.256(11.42)^{* * *}$ & $1.061(9.824)^{* * *}$ & $1.009(9.173)^{* * *}$ \\
\hline Constant & $0.312(1.821)^{*}$ & $0.230(2.240)^{* *}$ & 0.192 (1.750)* $^{*}$ \\
\hline $\bar{R}^{2}$ & 0.489 & 0.447 & 0.418 \\
\hline Number of observations & 300 & 300 & 300 \\
\hline
\end{tabular}

Note: In this and subsequent tables, the t-statistics are in parentheses; and *** means significant at the 1 per cent level, ** at the 5 per cent level, and * at the 10 per cent level, respectively.

Table 4 above summarizes the empirical results of regressing equation (5), using the complete sample data. The second and third columns present results from the pooled OLS model. The results indicate that an increase in income inequality, as represented by the after-tax Gini Coefficient, leads to a decline in personal savings rates. Not surprisingly, the coefficient on the per capita income growth variable is negative and significant, implying that an increase in per capita income growth leads to a decline in the savings rate. This is consistent with the presented relative income hypothesis, in the sense that if per capita income growth is primarily driven by higher income earners, as is the case for Canada over the sample period, then income inequality will increase, thereby inducing a decline in personal savings rates through expenditure cascade. As predicted by the theoretical model, the results so far may indicate that social factors that generate consumption interdependence are significant determinants of consumption and savings decisions of Canadians. The coefficient on the dependency ratio variable is negative but not statistically significant. Finally, the real interest rate variable has the expected positive sign and is statistically significant. As predicted by the theory, an increase in the interest rate leads to increased savings rates. 
By pooling the cross-sectional and time series data together, the pooled OLS approach ignores the panel structure of the data, and treats all the observations as serially uncorrelated and the error terms as homoscedastic. This is normally not the case. The existence of province-specific differences in income inequality, as discussed in section 2, and possibly other regressors, will give rise to heterogeneity and reduce the efficiency of the OLS results. To test for this, I conducted the BreuschPagan's Lagrange multiplier test. The null hypothesis — that there are no province-specific effects-is rejected, with a test statistic of 154.12 , which is greater than the 95 percent critical value of 9.48 from the chi-squared distribution. Panel data estimation techniques, such as the fixed and random effects estimators, are normally used to solve the problem by allowing for the existence of certain unobserved province effects.

The results from the random effects model are reported in the fourth and fifth columns of Table 4. The approach assumes that the unobserved province-specific effects are random and not correlated with the explanatory variables. The results are similar to those of the pooled OLS estimates except that the coefficient of the dependency ratio variable is now positive and statistically significant at the 10 percent significance level. The results imply that provinces that have higher dependency ratios tend to have higher personal savings rates. This may not be surprising if provinces with higher ratios of old and young people to the active working population are also the provinces where young children tend to work more and older people postpone their retirement: then, the results may be picking up that effect on the personal savings rate. Another difference is that the coefficient of the Gini is significantly larger in the random effects estimation, indicating a possible downward bias of the pooled OLS estimate.

The regression results for the fixed effects model are presented in the sixth and seventh columns of Table 4. The approach assumes that the unobserved province-specific effects are fixed, and correlated with the explanatory variables. The results are similar to those of the random effects model. To choose between the random effect and fixed effect models, I conducted the Hausman test to determine whether the unobserved province-specific effects are correlated with the explanatory variables. The test statistic of 5.75 is lower than the 95 -percent critical value of 9.48 from the chi-squared distribution. This suggests that the null hypothesis - that the individual (provincial) specific effects are uncorrelated with other regressors - cannot be rejected. Hence, though estimators of both random and fixed effects may be consistent, only the random effects estimators are efficient and thus must be the preferred estimation method.

To check robustness, I re-estimated all three models using Kuznets' ratio (ratio of the income of the top 20 percent income earners to that of the bottom 40 percent) as the measure of income inequality. The results are reported in Table 5. Consistent with the theory, all estimates for the income inequality variable have the expected negative coefficient and are statistically significant. The coefficients are again

Table 5. Income inequality and Personal Savings rate (Kuznets's Ratio).

\begin{tabular}{|c|c|c|c|}
\hline & OLS & Random effects & Fixed effects \\
\hline$I N Q_{i}$ & $-0.043(3.071)^{* *}$ & $-0.062(3.647)^{* * *}$ & $-0.063(3.510)^{* * *}$ \\
\hline$P C I g_{i-1}$ & $-0.252(2.598)^{* *}$ & $-0.228(2.621)^{* *}$ & $-0.225(2.586)^{* *}$ \\
\hline$D E P_{i}$ & $-0.098(1.581)$ & $0.130(1.826)^{*}$ & $0.202(1.981)^{*}$ \\
\hline$R_{i}$ & $1.225(12.01)^{* * *}$ & $1.034(9.942)^{* * *}$ & $0.987(9.311)^{* * *}$ \\
\hline Constant & $0.071(0.934)$ & $0.090(1.240)$ & $0.063(0.810)$ \\
\hline $\bar{R}^{2}$ & 0.468 & 0.4351 & 0.4159 \\
\hline Number of observations & 300 & 300 & 300 \\
\hline
\end{tabular}

Note: The dependent variable is the personal savings rate. All standard errors from the OLS model are corrected for heteroscedasticity. The t-statistics are in parentheses. See Table 4 note for coefficient significance indicators. 
significantly higher for the random and fixed effects models than the pooled OLS model, indicating a possible downward bias of the pooled OLS estimate of the income inequality variable. The results, with respect to the random effects model, show that all the variables are statistically significant. The Hausman test statistic of 3.62 is lower than the 95 -percent critical value of 9.48 from the chi-squared distribution. Again, this suggests that the null hypothesis - that the individual (provincial) specific effects are uncorrelated with other regressors — cannot be rejected. Hence, though estimators from both random and fixed effects may be consistent, only the random effects estimators are efficient.

The results, particularly with respect to the estimated coefficients for the income inequality and per capita income growth variables, are consistent with the findings of Yalnizyan (2010) that the richest 1 percent of Canadians took almost 32 percent of all income growth in the fastest growing decade (1997-2007), and also took almost a third of all growth in income of the slowest growing decade (1987-1997).

For more province-specific analysis, I estimated equation (5) for each of the provinces. Table 6 presents the results of using the after-tax Gini Coefficient as a measure of income inequality. The coefficient estimate for income inequality has the expected negative sign for eight of the ten provinces, though only seven of them are significant — at least, at the 10 percent significance level. Among them, Quebec has the greatest effect of income inequality on personal savings rates, followed by Ontario, Alberta, Manitoba, Newfoundland, British Columbia and Prince Edward Island. The two provinces with positive signs are Nova Scotia and Saskatchewan; however, only Saskatchewan has a significant positive relationship. Per capita income growth has no significant effect on savings rates in four of the ten provinces. For the other six provinces, the effect is predominantly negative, suggesting that growth in income in those provinces have primarily been driven by people in the higher income group. This has led to increasing income inequality, which in turn may have led to a reduction in the savings rate. For the majority of the provinces, the interest rate has a positive and significant effect on the savings rate. The effect of the dependency ratio on savings rates is mixed, with some provinces having positive and significant effects (Saskatchewan, Prince Edward Island, New Brunswick) and other provinces having negative and significant effects (Alberta, Quebec, Newfoundland). To check robustness, I re-estimated the model for the provinces using the Kuznets ratio to measure income inequality. From Table 7, we can see that the pattern, the direction, and the level of significance of the results are similar to those in Table 6.

Table 6. OLS estimates for Provinces (Gini Coefficient).

\begin{tabular}{|c|c|c|c|c|c|c|}
\hline $\begin{array}{l}\text { Canadian } \\
\text { Provinces }\end{array}$ & Gini $_{i}$ & $P C I g_{i-1}$ & $D E P_{i}$ & $R_{i}$ & Constant & $\bar{R}^{2}$ \\
\hline Alberta & $-1.546(2.34)^{* *}$ & $-0.066(1.97)^{* *}$ & $-1.121(3.73)^{* * *}$ & $0.353(1.23)$ & $1.149(3.23) * * *$ & 0.479 \\
\hline Brit. Columbia & $-0.941(1.98)^{* *}$ & $-0.314(1.87) *$ & $0.700(0.99)$ & $1.196(2.97)^{* * *}$ & $-0.023(0.04)$ & 0.794 \\
\hline Manitoba & $-1.156(1$ & $-0.227(C$ & 0.317( & $1.334(5.2$ & 0.2 & 0.708 \\
\hline New Brunswick & $-0.244(0.96)$ & $0.002(0.02)$ & $1.550(8.58)^{* * *}$ & $-0.076(0.48)$ & $95) * * *$ & 0.929 \\
\hline Newfoundland & $-1.423(1.67)^{*}$ & $-0.440(1.75) *$ & $-0.065(2.19) * *$ & $0.368(0.57)$ & 0.58 & 0.343 \\
\hline Nova Scotia & $0.063(0.13)$ & $-0.444(1.70)^{*}$ & $2.528(8.13)^{* * *}$ & $-0.050(0.35)$ & $3.96)^{* * *}$ & 0.935 \\
\hline Ontario & $-2.549(4.90)^{* * *}$ & ${ }^{k}-0.120(2.31)^{* *}$ & $0.194(0.43)$ & $0.437(1.99)^{* *}$ & 4)** $*$ & 0.833 \\
\hline Prince Ec & $-0.436(1.65)^{*}$ & $0.126(0.73)$ & $2.150(12.08)^{* * *}$ & $0.381(1.83)^{*}$ & $-0.894(6.16)^{* * *}$ & 0.933 \\
\hline Quebec & $-3.103(5.77)^{* * *}$ & ${ }^{k}-0.459(2.41)^{* *}$ & $-0.714(2.11)^{* *}$ & 0.108 (1.91)* & $1.519(3.54)^{* * *}$ & 0.828 \\
\hline Saskatchewan & $2.312(1.88)^{*}$ & $-0.053(0.2)$ & $1.255(2.15)^{* *}$ & $1.619(4.36)^{* *}$ & $-1.642(2.23)^{* *}$ & 0.672 \\
\hline
\end{tabular}

Note: The dependent variable is the personal savings rate. All standard errors are corrected for heteroscedasticity.

See Table 4 note for coefficient significance indicators. Number of observation for each regression is 30 . 
Darku: Income inequality, status seeking, and savings rates in Canada

Table 7. OLS estimates for Provinces (Kuznets's Ratio).

\begin{tabular}{llccccc}
\hline \multicolumn{1}{c}{$\begin{array}{c}\text { Canadian } \\
\text { Provinces }\end{array}$} & \multicolumn{1}{c}{$I N Q_{i}$} & \multicolumn{1}{c}{$P C I g_{i-1}$} & \multicolumn{1}{c}{$D E P_{i}$} & \multicolumn{1}{c}{$R_{i}$} & \multicolumn{1}{c}{ Constant } & $\bar{R}^{2}$ \\
\hline Alberta & $-0.155(3.36)^{* * *}$ & $-0.298(1.92)^{*}$ & $-1.403(5.42)^{* * *}$ & $0.227(0.97)$ & $1.121(5.54)^{* * *}$ & 0.536 \\
Brit. Columbia & $-0.090(1.72)^{*}$ & $-0.403(1.88)^{*}$ & $0.319(0.57)$ & $1.085(3.45)^{* * *}$ & $0.054(0.14)$ & 0.813 \\
Manitoba & $-0.144(2.18)^{* *}$ & $-0.242(1.04)$ & $-0.039(0.10)$ & $1.260(5.93)^{* * *}$ & $0.365(1.15)$ & 0.730 \\
New Brunswick & $-0.026(1.05)$ & $0.023(0.02)$ & $1.519(9.94)^{* * *}$ & $-0.035(0.49)$ & $-0.569(5.59)^{* * *}$ & 0.936 \\
Newfoundland & $-0.102(1.72)^{*}$ & $-0.397(1.84)^{*}$ & $-0.001(0.97)$ & $0.397(0.49)$ & $0.291(1.18)$ & 0.348 \\
Nova Scotia & $0.001(0.33)$ & $-0.385(1.67)^{*}$ & $2.506(9.23)^{* * *}$ & $-0.010(0.48)$ & $-1.122(6.54)^{* * *}$ & 0.946 \\
Ontario & $-0.215(6.28)^{* * *}$ & $-0.017(1.97)^{* *}$ & $0.059(0.37)$ & $0.329(2.13)^{* *}$ & $0.618(2.98)^{* *}$ & 0.855 \\
Prince Edw. Isl. & $-0.059(2.19)^{* *}$ & $0.198(1.25)$ & $2.147(13.01)^{* * *}$ & $-0.357(1.84)^{*}$ & $-0.913(8.64)^{* * *}$ & 0.950 \\
Quebec & $-0.240(4.01)^{* * *}$ & $-0.475(2.38)^{* *}$ & $-0.163(2.06)^{* *}$ & $0.401(1.68)^{*}$ & $0.723(1.91)^{*}$ & 0.785 \\
Saskatchewan & $0.179(1.74)^{*}$ & $-0.123(0.32)$ & $0.800(1.83)^{*}$ & $1.292(3.09)^{* *}$ & $-0.953(1.65)^{*}$ & 0.396 \\
\hline
\end{tabular}

Note: The dependent variable is the personal savings rate. All standard errors are corrected for heteroscedasticity.

See Table 4 note for coefficient significance indicators. Number of observation for each regression is 30 .

\section{Summary and policy implications}

Declining savings rates and rising income inequality are two important economic policy issues that confront many countries in recent times. Income inequality in Canada has risen considerably over the past three decades. Over the same period, personal savings rates have declined. According to Statistics Canada, personal savings rates have declined considerably, from double digits to single digits over the past three decades. This implies that consumption expenditure has grown more rapidly over the same period than what the traditional economic models predict. This paper uses Canadian provincial-level data and a variant of the relative income hypothesis proposed by Frank et al. (2010) to examine the relationship between income inequality and savings rates, while controlling for other standard determinants of savings rates. The theory predicts that increases in expenditure by some people in higher income groups, trigger increases in expenditure by people belonging to all income groups below, due to their desire to keep up with those just above them on the income ladder. Hence, increasing income inequality will lead to an expenditure cascade, which in turn leads to declining personal savings rates.

The empirical analysis led to some interesting findings. First, at the national level, increased income inequality has a significant negative effect on personal savings rates. At the provincial level, the relationship is also clear in eight of the ten provinces. The finding is consistent with Dornbusch and Edwards (1991), Aghion et al. (1999), and Persson and Tabellini (1994), although they used different theoretical models to demonstrate the negative relationship between income inequality and savings elsewhere than in Canada. The present results provide evidence that the negative relationship between income inequality and savings rates may be due to social behaviour such as status-seeking, and that prevailing models of consumer behaviour, such as the permanent income hypothesis and the life-cycle bypothesis, may need to take into consideration important social determinants of consumption and savings decisions. Second, both the national and provincial results imply that growth in per capita income that exacerbates income inequality impacts negatively on personal savings rates. Third, though the dependency ratio has a significant positive effect on personal savings rate the national level, there are mixed results at the provincial level. Some provinces have positive and significant effects (Saskatchewan, Prince Edward Island) and others have negative and significant effects (Alberta, Quebec, Newfoundland). Overall, the results were robust for different measures of income inequal- 
ity - for the preferred random effects model for the national results and for the OLS estimates for the provincial results. These results, therefore, present a clearer negative relationship between income inequality and personal savings rates, which is consistent with the observed pattern in the provincial and national data. There is, however, an important caveat. The decline in savings rates over a period of rising per capita income and income inequality may not necessarily indicate the existence of a consumption cascade. To pin down the relationship at the micro level, future studies should use household survey data on income and expenditures to establish the existence of a consumption cascade (if any) and then link it to the decline in savings rates.

From a policy point of view, this paper has highlighted the relative importance of social behaviour in discussing the dynamics of income inequality and its impact on overall economic performance. If an increase in income inequality leads to a decline in personal savings rates due to expenditure cascades, then the idea put forward by Kaldor (1957) and Pasinetti (1962) that inequality leads to economic growth through increased savings and capital accumulation cannot be entirely true. Therefore, policies to address income inequality would not only address an important economic menace that seems to grip many developed countries in the past few decades, but would be providing a critical foundation for stronger economic growth through their effect on savings rates.

\section{References}

Aghion, P., E. Caroli, and C. Garcia-Penalosa. 1999. Inequality and economic growth: The perspective of the new growth theories. Journal of Economic Literature 37:1615-1660.

Alesina, A., and D. Rodrik. 1996. Income distribution, political instability, and investment. European Economic Review 40:1203-1228.

1994. Distributive politics and economic growth. Quarterly Journal of Economics 109:465-490.

Ando, A., and Modigliani, F. 1963. The life-cycle hypothesis of savings: Aggregate implications and tests. American Economic Review 53:55-84.

Blinder, A. 1975. Distributional effects and the aggregate consumption function. Journal of Political Economy 27:444-475.

Borsch-Supan, A., Introduction to international comparison of household saving behaviour: A study of life-cycle savings in seven countries. Research in Economics 55:1-14.

Bosworth, B., 1993. Savings and Investment in a Global Economy. Washington: The Brookings Institution.

Brzozowski, M., Martin, M., Klein, P., and Suzuki, M. 2010. Consumption, income and wealth inequality in Canada. Review of Economic Dynamics 13:52-75.

Bunting, D., 1991. Savings and the distribution of income. Journal of Post Keynesian Economics 14:3-22.

Cook, C. 1995. Savings rates and income distribution: Further evidence from LDCs. Applied Economics 27:71-82.

Daly, M., W. Margo, and V. Shawn. 2001. Income inequality and homicide rates in Canada and the United States. Journal of Criminology 43:219-236.

Della, P., and P. Oguchi. Distribution, the aggregate consumption function and the level of economic development: Some cross-section results. Journal of Political Economy 84:1325-1334.

Deaton, A. 1992. Understanding Consumption. Oxford: Clarendon Press. 
Darku: Income inequality, status seeking, and savings rates in Canada

Duesenberry, J. 1949. Income, savings and the theory of consumption behaviour. Cambridge MA: Harvard University Press.

Dornbusch, R., and S. Edwards. 1991. The macroeconomics of populism, in The Macroeconomics of Populism in Latin America, edited by R. Dornbusch and S. Edwards. Chicago: University of Chicago Press.

Dynan, K., J. Skimmer, and S. Zeldes. 1996. Do the Rich Save More? Unpublished manuscript.

Edwards, S. 1996. Why are Latin America's savings rates so low? An international comparative analysis. Journal of Development Economics 51:5-44.

Frank, R., A. Levine, and O. Dijk. 2010. Expenditure Cascades. Available at SSRN: http://ssrn.com/ abstract=1690612 or http://dx.doi.org/10.2139/ssrn.1690612.

Friedman M. 1957. A Theory of the Consumption Function. Princeton, NJ: Princeton University Press.

Honk, K. 1995. Income Distribution and Aggregate Savings. Unpublished manuscript. Cambridge MA: Harvard University.

Jin, Y., H. Li, and B. Wu. 2011. Income inequality, consumption, and social-status seeking. Journal of Comparative Economics 39:191-204.

Kaldor, N. 1957. A model of economic growth. Economic Journal 67:590-624.

Keynes, M. 1936. The General Theory of Employment, Interest and Money. New York: Harcourt.

Kotlikoff, L., and L. Summers. 1981. The role of intergenerational transfers in aggregate capital accumulation. Journal of Political Economy 89:706-732.

Lewis, A. 1954. Economic development with unlimited supply of labour. The Manchester School 22:139_ 191.

Li, H., and H. Zou. 2004. Savings and income distribution. Annals of Economics and Finance 5:245-270.

Modigliani, F., and R. Brumberg. 1955. Utility analysis and the consumption function: An interpretation of cross-section data, in Post Keynesian Economics, edited by K. Kurihara. London: Allen and Unwin.

Musgrove, P. 1980. Income distribution and the aggregate consumption function. Journal of Political Economy 88:504-525.

Osberg, L. 2012. Instability Implications of Increasing Inequality: What Can Be Learned From North America? Ottawa: Canadian Centre for Policy Alternatives.

Pasinetti, L. 1962. Rate of profit and income distribution in relations to the rate of economic growth. Review of Economic Studies 29:267-279.

Persson, T., and G. Tabellini. 1994. Is inequality harmful for growth? Theory and evidence. American Economic Review 84:600-621.

Raphael, D. 2002. Poverty, Income Inequality and Health in Canada. Toronto: CJS Foundation for Research and Education.

Saez, E., and M. Veall. 2005. The evolution of high incomes in North America: Lessons from Canadian evidence. American Economic Review 95:831-849.

Schmidt-Hebbel, K., and L. Serven. 2000. Does income inequality raise aggregate saving? Journal of Development Economics 64:417-446. 
Smith, D. 2001. International evidence on how income inequality and credit market imperfections affect private savings rates. Journal of Development Economics 64:103-127.

Thaler, R. 1994. Psychology and savings policies. The American Economic Review 84:186-192.

Venieris, Y., and D. Gupta. 1986. Income distribution and sociopolitical instability as determinants of savings: A cross-sectional model. Journal of Political Economy 94:873-883.

Wilson, D., and D. Macdonald. 2010. The Income Gap between Aboriginal Peoples and the Rest of Canada. Ottawa: Canadian Centre for Policy Alternatives.

Wisman, J. 2009. Household savings, class identity, and conspicuous consumption. Journal of Economic Issues 1:89-113.

Yalnizyan, A. 2010. The Rise of Canada's Richest 1\%. Ottawa: Canadian Centre for Policy Alternatives. 